\title{
Pathogenicity of Listeria monocytogenes isolates in immunocompromised mice in relation to listeriolysin production
}

\author{
M. TABOURET, J. DE RYCKE*, A. AUDURIERt and B. POUTREL \\ Institut National de la Recherche Agronomique, Station de Pathologie de la Reproduction, 37380 Nouzilly and \\ tLaboratoire de Bactériologie, Faculté de Médecine, 37032 Tours, France
}

\begin{abstract}
Summary. The virulence of 74 Listeria monocytogenes isolates from clinical cases and food products and of 11 isolates of other Listeria species was tested in mice immunocompromised with carrageenan. Isolates of species other than $L$. monocytogenes were not lethal to such mice. All 29 clinical isolates of $L$. monocytogenes (serotypes $1 / 2 \mathrm{a}, 1 / 2 \mathrm{~b}, 4 \mathrm{~b}$ ) and 33 of 42 isolates of various serotypes isolated mainly from dairy products killed all test mice $(100 \%$ lethality) at an inoculum of $10^{4} \mathrm{cfu} /$ mouse. All lethal strains of $L$. monocytogenes were haemolytic and possessed the 58-Kda band specific for listeriolysin $\mathrm{O}$ as demonstrated by SDS-PAGE immunoblotting. The nine avirulent strains of $L$. monocytogenes had detectable haemolytic activity, but in six of them this activity was significantly weaker than in virulent strains and the 58-Kda band was not detected. The other three avirulent strains were highly haemolytic and possessed the 58-Kda band, which suggests that other factor(s) could be involved in the virulence of $L$. monocytogenes.
\end{abstract}

\section{Introduction}

The genus Listeria includes five recognised species, ${ }^{1}$ of which only L. monocytogenes is regularly involved in human diseases. Pregnant women, neonates and more generally immunocompromised patients are particularly susceptible to listeriosis, although the disease sometimes occurs in apparently healthy individuals. Listeriosis is generally sporadic but large outbreaks have occurred in which the role of food products, mainly dairy products, has been clearly demonstrated. ${ }^{2}$

The virulence of $L$. monocytogenes for man has been correlated with pathogenicity in mice, ${ }^{3,4}$ particularly in mice immunocompromised by treatment with carrageenan. ${ }^{5}$ In this model, a large difference between the LD50 of virulent and avirulent species is observed. This characteristic, not observed in normal mice, affords a clear and rapid means of distinguishing between strains with a single dose inoculum and with the sole criterion being death of mice.

The major virulence factor of $L$. monocytogenes is an extracellular thiol-activated haemolysin, listeriolysin O (LLO). ${ }^{6}$ This has been identified as a protein of $58 \mathrm{Kda}$ by sodium dodecyl sulphate-polyacrylamide gel electrophoresis (SDS-PAGE). The role of LLO in virulence has been demonstrated in tests with nonhaemolytic mutants obtained by transposon muta-

Received 19 April 1990; accepted 10 June 1990.

* Correspondence should be sent to Dr J. De Rycke, Institut National de la Recherche Agronomique, Station de Pathologie de la Reproduction, 37380, Nouzilly, France. genesis. $^{7-11}$ However, this has been done with laboratory strains and needs to be confirmed with a large and representative sample of strains from clinical cases and food products. The purpose of this study was to examine the association between the production of LLO and virulence in field isolates. Some $L$. monocytogenes isolates are avirulent $;^{12-15}$ therefore, we first screened a large number of clinical and food isolates for virulence in mice immunocompromised with carrageenan. ${ }^{5}$ Having confirmed the existence of avirulent strains we then investigated the association of virulence with haemolysin production and with the possession of the $58-\mathrm{Kda}$ protein band specific for LLO.

\section{Materials and methods}

\section{Bacteria}

Strains of Listeria used in this study are shown in the table; 70 strains were from the collection of the Centre Hospitalier Universitaire de Tours, France. Of the total of $74 \mathrm{~L}$. monocytogenes isolates, $46 \%$ were from dairy products (raw milk and cheese) and 39\% from human or animal clinical cases. The latter were either from sporadic cases (eight strains) or from outbreaks in man-Angers, France (four strains); ${ }^{16}$ Nova Scotia, Canada (three strains) $;{ }^{17}$ Boston, USA (five strains); ${ }^{18}$ Los Angeles, USA (seven strains); $;^{19}$ Lausanne, Switzerland (two strains) (J. Bille, personal communication). Three other L. monocytogenes strains, kindly provided by $P$. Berche (Faculté de 
Table. Characteristics of Listeria strains used

\begin{tabular}{|c|c|c|c|c|c|}
\hline Species & Source & $\begin{array}{c}\text { Pathogenicity* in } \\
\text { immunocompromised } \\
\text { mice }\end{array}$ & $\begin{array}{c}\text { Haemolysis } \dagger \\
\text { on sheep-blood } \\
\text { agar }\end{array}$ & Serotype (number of isolates) $\ddagger$ & $\begin{array}{l}\text { Total number } \\
\text { of strains }\end{array}$ \\
\hline L. innocua & Cheese, cow & - & - & $4 \mathrm{ab}, 6 \mathrm{a}, \mathrm{ND}(2)$ & 4 \\
\hline L. seeligeri & Milk, silage & - & + & $1 / 2 \mathrm{a}, 1 / 2 \mathrm{~b}, \mathrm{ND}$ & 3 \\
\hline L. ivanovii & Milk, sheep & - & +++ & $5(3)$ & 3 \\
\hline L. welshimeri & Vegetation & - & - & $6 a$ & 1 \\
\hline \multirow{6}{*}{ L. monocytogenes } & Clinical cases & + & ++ & $1 / 2 \mathrm{a}(2), 1 / 2 \mathrm{~b}(3), 4 \mathrm{~b}(24)$ & 29 \\
\hline & Dairy products & + & ++ & $1 / 2 \mathrm{a}(12), 1 / 2 \mathrm{~b}(2), 1 / 2 \mathrm{c}, 3 \mathrm{~b}, 4 \mathrm{~b},(10)$ & 26 \\
\hline & ? & + & ++ & $3 \mathrm{~b}, 3 \mathrm{c}, 4 \mathrm{a}, 4 \mathrm{c}, 4 \mathrm{~d}, 4 \mathrm{e}, 7$ & 7 \\
\hline & $?$ & - & ++ & $3 a$ & 1 \\
\hline & Dairy products & - & $+t$ & $1 / 2 \mathrm{a}(2)$ & 2 \\
\hline & Dairy products & - & + & $1 / 2 a(6)$ & 6 \\
\hline
\end{tabular}

$*+, 100 \%$ mortality; - , no deaths in 5 days

$\dagger-$, No haemolysis; + , weak haemolysis $;++$, clear haemolysis $;+++$, strong haemolysis.

$\ddagger$ For number greater than one.

$\mathrm{ND}=$ not determined

$?=$ Unknown

Médecine Necker-Enfants Malades, Paris, France), were used as controls-L.monocytogenes EGD (NCTC 7973), its hly ${ }^{-}$mutant obtained by transposon mutagenesis with $\mathrm{Tn} 1545$, and the hly ${ }^{+}$revertant of the latter strain. $^{7}$

\section{Species identification ${ }^{20}$}

Identification of Listeria was confirmed by testing the following properties: production of acid from $D-$ xylose $(1 \%)$, L-rhamnose $(1 \%)$ and $\alpha$-methyl-D-mannoside $(0.5 \%)$, haemolysis on Tryptose Soy Agar (TSA; Biomérieux) containing washed sheep red blood cells $(5 \% \mathrm{v} / \mathrm{v})$, and the Camp test reaction with Staphylococcus aureus (CIP 5710) and with Rhodococcus equi (CIP 5869).

\section{Pathogenicity in immunocompromised mice}

Bacterial strains were tested blindly in 5-week-old female Swiss OF1 mice (IFFA credo, France) weighing 20-25 $\mathrm{g}$ and kept under controlled temperature $\left(21^{\circ} \mathrm{C}\right)$, humidity $(60 \%)$ and light intensity. Carrageenan (Sigma, type II) dissolved in distilled water was injected intraperitoneally $(200 \mathrm{mg} / \mathrm{kg}), 24 \mathrm{~h}$ before challenge. Bacterial isolates were grown for $24 \mathrm{~h}$ at $37^{\circ} \mathrm{C}$ on Brain Heart Infusion Agar (BHIA; Difco) and harvested in saline. Each suspension was standardised turbidimetrically, adjusted to $5 \times 10^{4} \mathrm{cfu} / \mathrm{ml}$ by dilution in saline and $0.2 \mathrm{ml}$ was administered by intraperitoneal injection (i.e., $10^{4} \mathrm{cfu} /$ mouse). Sets of five mice received each isolate. In each experiment, control groups of mice were given known pathogenic and non-pathogenic strains, or saline alone. Mice were then observed for 6 days and death was recorded. The inoculum was checked by enumeration of bacterial colonies on TSA.

\section{Titration of haemolytic activity}

Haemolytic activity was assayed in the culture supernates of bacteria grown in Proteose-Peptone Broth treated with charcoal (CTB) as described previously. ${ }^{21}$ From an overnight culture, $125 \mu$ l was inoculated into $5 \mathrm{ml}$ of the same medium and incubated at $37^{\circ} \mathrm{C}$ for $10 \mathrm{~h}$. Supernates were collected after centrifugation $\left(10000 \mathrm{~g}\right.$ for $10 \mathrm{~min}$ at $4^{\circ} \mathrm{C}$ ) and assayed for haemolytic activity by the modified method of Alouf et al..$^{22}$ in flat-bottomed polystyrene microtitration plates (Greiner). A 100- $\mu$ l volume of a twofold dilution of culture supernate in phosphate-buffered saline (PBS, pH 6.0) was added to $50 \mu$ l of sheep-redblood-cell (SRBC) suspension (2.25\%) in PBS supplemented with $40 \mathrm{mM}$ DL-cysteine (Aldrich) and bovine albumin (Miles) $0 \cdot 2 \%$. Plates were then incubated at $37^{\circ} \mathrm{C}$ for $45 \mathrm{~min}$, centrifuged ( $1000 \mathrm{~g}$ for $2 \mathrm{~min}$ ), and the haemoglobin in the supernates was measured spectrophotometrically in a Titertek Multiskan apparatus (Flow Laboratories) at $541 \mathrm{~nm}$. One haemolytic unit (HU) was defined as the amount of toxin causing the release of $50 \%$ of the haemoglobin of erythrocytes and was estimated from a standard graph. ${ }^{22}$

\section{Detection of LLO by electrophoresis and immunoblotting}

Bacteria were grown overnight in $\mathrm{CTB}$ at $37^{\circ} \mathrm{C}$ and centrifuged $\left(5000 \mathrm{~g}\right.$ for $20 \mathrm{~min}$ at $\left.4^{\circ} \mathrm{C}\right)$. Supernates were treated with trichloroacetic acid (TCA) $10 \%$ and precipitates were collected by centrifugation $(11000 \mathrm{~g}$ for $20 \mathrm{~min}$ at $4^{\circ} \mathrm{C}$ ) then dissolved in $0.06 \mathrm{M}$ Tris $\mathrm{HCl}$ buffer ( $\mathrm{pH}$ 6.8). Protein concentration was determined by the method of Bradford. ${ }^{23}$ Samples were then diluted in an equal volume of sample buffer (SDS $2 \%$, glycerol $10 \%$, mercaptoethanol $5 \%$, bromophenol blue $0.002 \%, 0.02 \mathrm{M}$ Tris $\mathrm{HCl}$ ) and boiled for $3 \mathrm{~min}$. SDS- 
PAGE was performed in $7.5 \%$ resolving gels by the method of Laemmli ${ }^{24}$ with approximately $100 \mu \mathrm{g}$ of protein/well. After electrophoresis, separated proteins were transferred on to nitrocellulose membranes (Sartorius) $^{25}$ by means of a semi-dry fast electroblotter (Biometra). The nitrocellulose was then saturated overnight with gelatine $0.5 \%$ solution and incubated for $1.5 \mathrm{~h}$ in anti-listeriolysin $\mathrm{O}$ serum (kindly provided by $P$. Berche, Faculté de Medecine Necker-Enfants Malades, Paris, France) ${ }^{6}$ diluted 1 in 400 in PBS containing Tween $200.1 \%$ and gelatine $0.5 \%$ (PBST-G). After three washings in PBS containing Tween $200 \cdot 1 \%$ (PBS-T) the nitrocellulose paper was incubated for $1 \mathrm{~h}$ with goat anti-rabbit immunoglobin $\mathrm{G}$ linked to horseradish peroxidase (Nordic) diluted 1 in 1000 in PBS-T-G. After two washes in PBS-T and two in PBS, immunoreactive bands were revealed by treatment with 4-chloro-1-naphtol (HRP colour development reagent; Bio- $\mathrm{Rad}) 0.5 \mathrm{mg} / \mathrm{ml}$ and $\mathrm{H}_{2} \mathrm{O}_{2}$ $0.03 \% \mathrm{v} / \mathrm{v}$.

\section{Results}

\section{Confirmation of identity of Listeria species}

The identity of the isolates as Listeria was confirmed by the criteria described in Materials and methods. We noted that $11(13 \%)$ L. monocytogenes strains reduced $\alpha$-methyl-D-mannoside in 4-7 days compared with 12 days for the other isolates.

\section{Pathogenicity of isolates for immunocompromised mice}

Mice were not affected by injection of carrageenan alone. After a slight decrease of weight (approximately
$1.5 \mathrm{~g}$ ) during the first $24 \mathrm{~h}$, no sign of discomfort or toxicity was observed during the whole period of the experiment. Mice regained their initial weight $48 \mathrm{~h}$ after injection and then had a normal growth rate.

With an inoculum of $10^{4} \mathrm{cfu}$ and a period of observation of 5 days, the 85 Listeria isolates could be classified as either pathogenic (four or five deaths out of five mice inoculated) or non-pathogenic (no death out of five mice). On re-testing two or three times, the six isolates that caused four deaths out of five were $100 \%$ lethal. No significant difference was observed in the mean time to death with pathogenic strains. Death occurred between 2 and 5 days after inoculation and, usually $(75 \%)$, between 72 and $96 \mathrm{~h}$.

The pathogenicity of Listeria isolates according to species, serotype and source is shown in the table. None of 11 isolates of species other than L. monocytogenes were pathogenic. Of the L. monocytogenes strains, all 29 clinical isolates (serotypes $1 / 2 \mathrm{a}, 1 / 2 \mathrm{~b}, 4 \mathrm{~b}$ ) and 33 $(79 \%$ ) out of 42 isolates from other sources (mainly dairy products) were pathogenic. The nine nonpathogenic strains belonged to serotypes $1 / 2 a$ (eight strains) and $3 \mathrm{a}$ (one strain), whereas no non-pathogenic strains were detected among the 10 strains of serotype $4 \mathrm{~b}$. The lack of pathogenicity of the nine $L$. monocytogenes strains was confirmed on re-testing.

The transposon-induced mutant, which lacks LLO (EGD hly ${ }^{-}$), was not pathogenic, in contrast to both the parent and revertant (EGD hly ${ }^{+}$) strains.

\section{Association between pathogenicity and haemolysin production}

All the strains were examined for haemolytic activity in a single experiment with the same batch of SRBC (fig. 1). The highest activities were produced

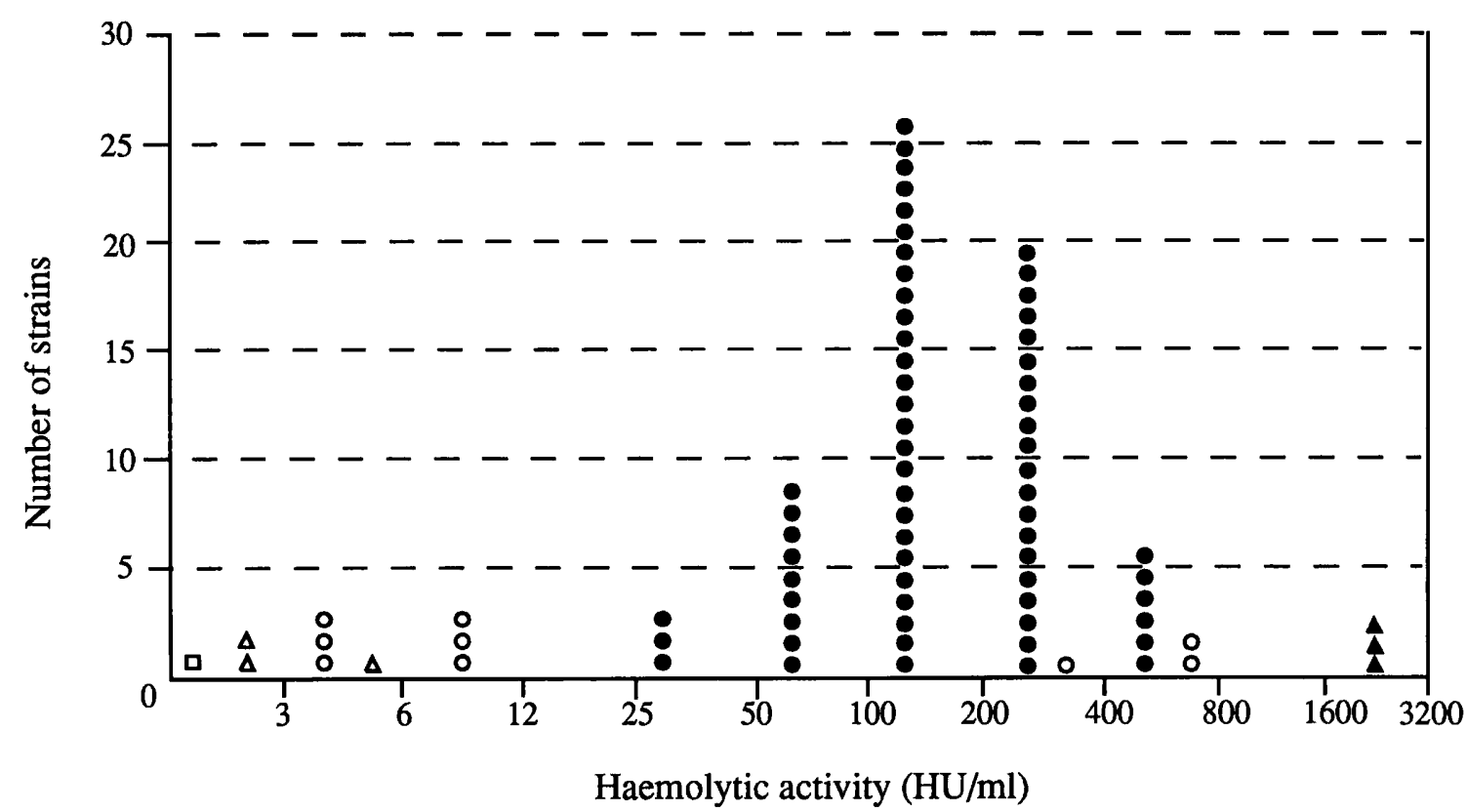

Fig. 1. Distribution of haemolytic activity in CTB culture supernates of Listeria strains: $\Delta$, L. ivanovii ( 3 strains); $\triangle$, L. seeligeri ( 3 strains); , L. monocytogenes lethal for mice (64 strains); $O, L$. monocytogenes not lethal for mice (9 strains); $\square, L$. monocytogenes EGD hly ${ }^{-}$obtained by transposon mutagenesis. No haemolytic activity was detected in supernates of $L$. innocua (4 strains) and $L$. welshimeri (1 strain). 

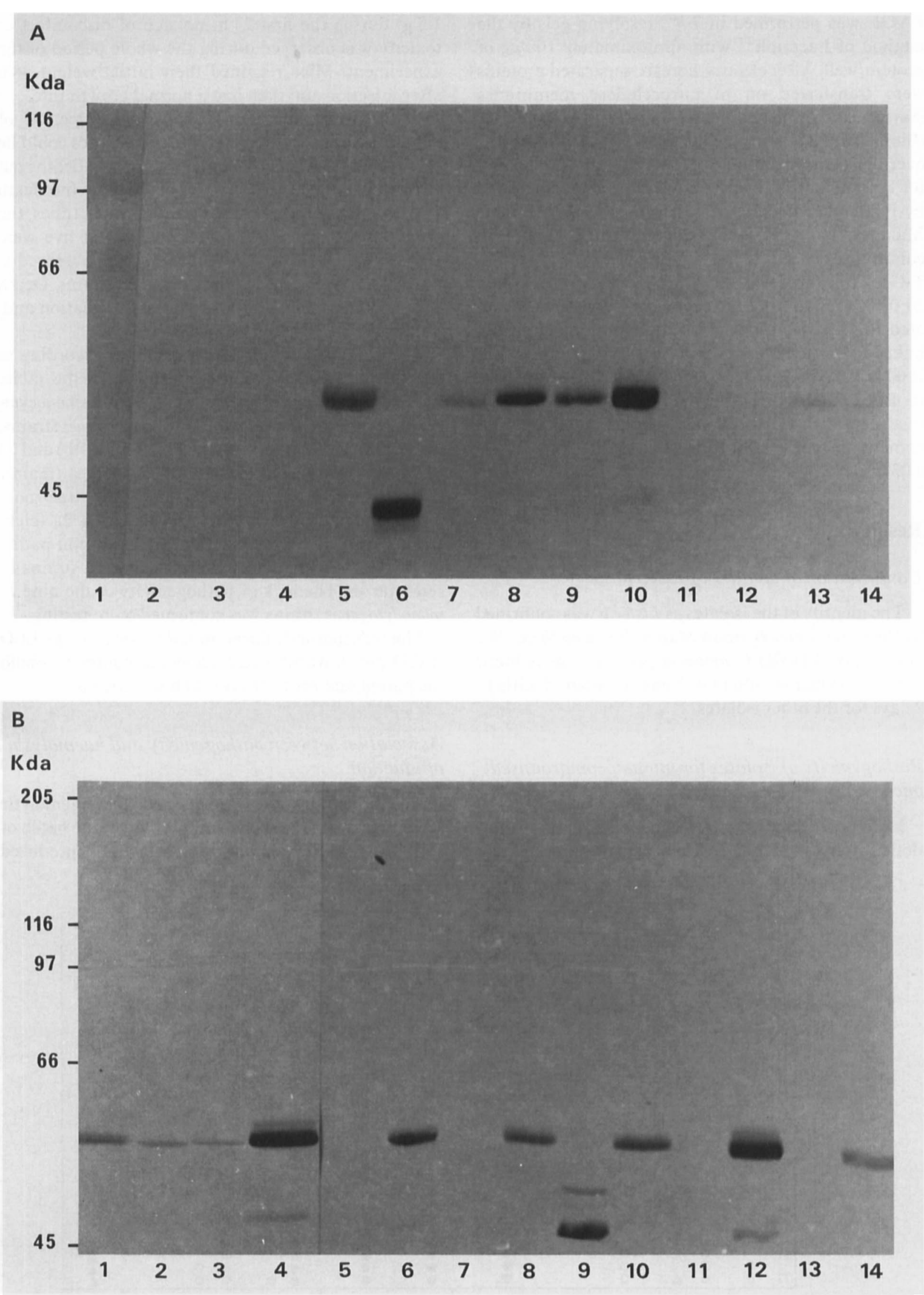

Fig. 2. Immunodetection of listeriolysin in culture supernates after electrophoresis on SDS-polyacrylamide gels. The blot was developed with rabbit anti-listeriolysin $\mathrm{O}$ serum (1 in 400). (A) Lane 1, mol.-wt markers; 2 , L. innocua ; 3, L. seeligeri $; 4, L$. welshmeri; 5 L. ivanovii; 6 , mutant $L$. monocytogenes EGD hly ${ }^{-} ; 7$, revertant $L$. monocytogenes EGD hly ${ }^{+} ; L$. monocytogenes isolates lethal for mice from $(8,9)$ dairy products and from $(10,13,14)$ clinical cases; 11,12 weakly haemolytic $L$. monocytogenes isolates not lethal for mice. (B) $L$. monocytogenes isolates lethal for mice from $(1,2)$ clinical cases and from $(3,4,14)$ dairy products; weakly haemolytic $(5,7,11,13)$ and highly haemolytic $(6,10,12)$ L. monocytogenes isolates not lethal for mice; 8, wild strain $L$. monocytogenes EGD and (9) its mutant $L$. monocytogenes EGD hly ${ }^{-}$used as controls. 
by L. ivanovii strains (1600-2500 HU/ml). As expected, the Tn 1545-induced (hly ${ }^{-}$) mutant of L. monocytogenes EGD had no detectable haemolytic activity. The mean haemolytic activity of all other L. monocytogenes strains was $128 \mathrm{HU} / \mathrm{ml}$. The nine non-pathogenic isolates belonged to two distinct groups-weakly haemolytic (six isolates with activity of 5-8 HU/ml) and highly haemolytic (three isolates with activities of $200,500$ and $600 \mathrm{HU} / \mathrm{ml})$. The mean activity of the six weakly haemolytic strains $(6 \cdot 2 \mathrm{HU} / \mathrm{ml})$ was significantly different from the mean activity of all other $L$. monocytogenes strains $(167 \mathrm{HU} / \mathrm{ml})(\mathrm{t}=12 \cdot 7, \mathrm{p}<$ $0.0005)$. Haemolytic activity correlated with intensity of haemolysis on blood agar (table).

Supernates of overnight cultures were tested for the presence of the 58-Kda LLO by immunoblotting with specific antiserum. This experiment was performed on 26 representative strains of $L$. monocytogenes and one strain of each other species. The $L$. monocytogenes strains included eight clinical isolates (all pathogenic) of various serotypes and 15 isolates from dairy products including the nine non-pathogenic strains. All pathogenic $L$. monocytogenes isolates possessed the LLO band (fig. 2). This band was also detected in L. ivanovii and in the three non-pathogenic, highly haemolytic $L$. monocytogenes strains. In contrast, LLO was not detected in isolates of $L$. innocua, $L$. welshimeri and $L$. seeligeri, or in the six weakly haemolytic and nonpathogenic L. monocytogenes isolates. The $58-\mathrm{Kda}$ protein band was also absent from the hly ${ }^{-}$transposoninduced mutant of $L$. monocytogenes $\mathrm{EGD}$, being replaced, as previously described, ${ }^{7}$ by several bands of $45-55 \mathrm{Kda}$ (fig. 2). The LLO band was present in the hly ${ }^{+}$revertant of the hly ${ }^{-}$strain.

\section{Discussion}

To investigate the variation in pathogenicity of field isolates of Listeria spp., a simple and reliable assay of virulence applicable on a large scale is required. The model of mice immunocompromised with carrageenan seemed to serve this purpose, because according to Stelma et al., ${ }^{5}$ a single inoculum of $10^{4} \mathrm{cfu}$ was able to distinguish pathogenic from non-pathogenic strains. The relevance of this model to the natural infection is further supported by the well-established predilection of $L$. monocytogenes for immunocompromised hosts. Our results confirm and extend the previous observations of Stelma et al. ${ }^{5}$ on an enlarged sample of isolates. Indeed, all 29 L. monocytogenes isolates from clinical cases killed all test mice whereas the 11 isolates of other Listeria spp. were totally non-pathogenic. Such results are also in agreement with those obtained with normal mice ${ }^{26}$ except in tests with $L$. ivanovii strains, which are generally found to be pathogenic in the latter model. ${ }^{3}$ The absence of pathogenicity observed in the present study with the hly ${ }^{-}$transposoninduced mutant also confirms previous studies in which normal mice were used. ${ }^{7}$

In contrast to clinical isolates, a significant propor- tion $(21 \%)$ of $L$. monocytogenes isolates from food products were non-pathogenic in immunocompromised mice. It is important to note the different distribution of non-pathogenic strains in serotypes $1 / 2 a$ and $4 b$, the two serotypes most frequently incriminated in human listeriosis: $40 \%$ (8 of 20$)$ of $1 / 2 \mathrm{a}$ isolates were non-pathogenic, compared with none of $104 \mathrm{~b}$ isolates. The higher proportion of virulent strains in serotype $4 \mathrm{~b}$ is reflected in the fact that, although less frequent than isolates of serotype $1 / 2 \mathrm{a}$ in food products, they are more frequently isolated from clinical cases. ${ }^{27,28}$

The immunocompromised mouse model was also used recently by Conner et al..$^{29}$ to test the pathogenicity of foodborne, environmental and clinical isolates of $L$. monocytogenes. As in the present study, they detected non-lethal isolates $(7 \%)$, but in contrast, they also reported a large number of isolates with "intermediary pathogenicity". However, the LD50 of isolates classified as "intermediary" was similar to that of fully pathogenic strains and was several orders of magnitude lower than that of "non-pathogenic" isolates, suggesting that the "intermediary" isolates could be classified justifiably as pathogenic. This apparent discrepancy between our results and those of Conner $e$ e al. ${ }^{29}$ probably reflects the difference in the duration of the observation period; we found that a 5day period gave unambiguous results, whereas results after 3 days, as used by Conner $e t$ al., were ambiguous. Small differences in experimental procedures, such as the strain of mouse used, could also contribute to the observed differences between the two studies.

The main purpose of this study was to test the association between the production of LLO and the pathogenicity of L. monocytogenes isolates. All isolates classified as pathogenic in the immunocompromised mouse model produced a detectable amount of haemolysin and possessed the 58-Kda band specific for LLO, confirming previous observations. ${ }^{21}$ However, previous studies had not included non-pathogenic field isolates. These isolates could be classified into two categories. The first category included six isolates that produced a very small amount of haemolysin and no detectable LLO in SDS-PAGE immunoblotting. The absence of pathogenicity in isolates in this category is probably due to insufficient production of LLO, which has previously been demonstrated to be a crucial factor in the intracellular survival and multiplication of $L$. monocytogenes. ${ }^{30-32}$ We suggest that production of LLO above a minimal threshold level is necessary to allow intracellular growth of L. monocytogenes. All isolates of this category had a further remarkable characteristic-reduction of $\alpha$-methyl-D-mannoside only after a significant delay, a property which was observed in only $8 \%$ of pathogenic isolates.

The other category of non-pathogenic isolates of $L$. monocytogenes, includes three strains that produced a large quantity of haemolysin and the $58-\mathrm{Kda}$ band specific for LLO. The role of LLO in pathogenicity 
has been clearly established. We can put forward two hypotheses to explain the lack of virulence in these strains. The first is that, although almost identical to the LLO of pathogenic strains, the haemolysin of this category of strains differs in amino-acid sequences which are crucial for intracellular growth but which are unrelated to the mechanism of haemolysis. Such a hypothesis has been suggested to account for the difference of virulence observed between haemolytic species of Listeria, i.e. L. monocytogenes, $L$. ivanovii and $L$. seeligeri. ${ }^{4}$ An alternative, and more likely, explanation is that another critical factor of pathogenicity is lacking in this category of non-pathogenic strains. Such a factor could be required, for example, for entry of organisms into cells, a crucial step in pathogenicity which is characteristic of $L$. monocytogenes when compared with other Listeria spp. ${ }^{30}$ It has indeed been demonstrated that hly ${ }^{-}$mutants of $L$. monocytogenes are still capable of penetration but cannot survive within cells. ${ }^{9,30,31}$ In this context, we are currently investigating possible differences in surface antigens between pathogenic and non-pathogenic strains.

This study shows the existence of a significant proportion of potentially non-pathogenic strains of $L$. monocytogenes in food products, and highlights the importance of recognising such strains in the laboratory. Furthermore, it indicates that, in addition to LLO, other critical factor(s) responsible for pathogenicity may be present in virulent strains of L. monocytogenes.

We are grateful to P. Berche, J. Bille, E. P. Espaze and J. Rocourt for providing some of the Listeria strains used in this study, E. P. Espaze for the serotyping of non- $4 \mathrm{~b} L$. monocytogenes, $H$. Le Roux and E. Rabouan for the care of mice and P. Menanteau for photographic assistance. This work was supported by a grant from the Conseil Régional de la Région Centre (France).

\section{References}

1. Rocourt J, Grimont F, Grimont PAD, Seeliger HPR. DNA relatedness among serovars of Listeria monocytogenes sensu lato. Curr Microbiol 1982; 7: 383-388.

2. Griffiths MW. Listeria monocytogenes: its importance in the dairy industry. J Sci Food Agric 1989; 47: 133-158.

3. Rocourt J, Alonso J-M, Seeliger HPR. Virulence comparée des cinq groupes génomiques de Listeria monocytogenes (sensu lato). Ann Inst Pasteur Microbiol 1983; 134A : 359-364.

4. Mainou-Fowler T, Macgowan AP, Postlethwaite R. Virulence of Listeria spp.: course of infection in resistant and susceptible mice. J Med Microbiol 1988; 27 : 131-140.

5. Stelma GN, Reyes AL, Peeler JT et al. Pathogenicity test for testing Listeria monocytogenes using immunocompromised mice. J Clin Microbiol 1987; 25: 2085-2089.

6. Geoffroy C, Gaillard J-L, Alouf JE, Berche P. Purification, characterization, and toxicity of the sulfhydryl-activated hemolysin listeriolysin $\mathrm{O}$ from Listeria monocytogenes. Infect Immun 1987; 55: 1641-1646.

7. Gaillard J-L, Berche P, Sansonetti P. Transposon mutagenesis as a tool to study the role of hemolysin in the virulence of Listeria monocytogenes. Infect Immun 1986; 52: 50-55.

8. Kathariou S, Metz P, Hof H, Goebel W. Tn916-induced mutations in the hemolysin determinant affecting virulence of Listeria monocytogenes. J Bacteriol 1987; 169: 12911297.

9. Portnoy DA, Jacks PS, Hinrichs DJ. Role of hemolysin for the intracellular growth of Listeria monocytogenes. J Exp Med 1988; 167: 1459-1471.

10. Camilli A, Paynton CR, Portnoy DA. Intracellular methicillin selection of Listeria monocytogenes mutants unable to replicate in a macrophage cell line. Proc Natl Acad Sci USA $1989 ; 86$ : 5522-5526.

11. Cossart P, Vicente MF, Mengaud J, Baquero F, Perez-Diaz JC, Berche $P$. Listeriolysin $O$ is essential for virulence of Listeria monocytogenes: direct evidence obtained by gene complementation. Infect Immun 1989; 57: 3629-3636.

12. Von Koenig CHW, Heymer B, Hof H, Finger H. Course of infection and development of immunity in experimental infection of mice with Listeria serotypes. Infect Immun $1983 ; 40: 1170-1177$.

13. Hof H. Virulence of different strains of Listeria monocytogenes serovar 1/2a. Med Microbiol Immunol (Berl) 1984; 173: 207-218.

14. Lovett J, Francis DW, Hunt JM. Listeria monocytogenes in raw milk: detection, incidence, and pathogenicity. J Food Prot 1987; 50: $188-192$.

15. Pine L, Weaver RE, Carlone GM et al. Listeria monocytogenes ATCC 35152 and NCTC 7973 contain a nonhemolytic, nonvirulent variant. J Clin Microbiol $1987 ; 25: 2247-2251$.

16. Carbonnelle B, Cottin J, Parvery F et al. Epidémie de listériose dans l'ouest de la France (1975-1976). Ref Epidemiol Santé Publique (Paris) 1978; 26: 451-467.

17. Schlech WF, Lavigne PM, Bortolussi RA et al. Epidemic listeriosis-evidence for transmission by food. $N$ Engl J Med 1983; 308: 203-206.

18. Fleming DW, Cochi SL, MacDonald KL et al. Pasteurized milk as a vehicle of infection in an outbreak of listeriosis. N Engl J Med 1985; 312: 404-407.

19. Linnan MJ, Mascola M, Xiao DL et al. Epidemic listeriosis associated with Mexican-style cheese. $N$ Engl J Med 1988; 319: $823-828$.

20. Rocourt J, Schrettenbrunner A, Seeliger HPR. Différenciation biochimique des groupes génomiques de Listeria monocytogenes (sensu lato). Ann Inst Pasteur Microbiol 1983; 134A : 65-71.

21. Geoffroy C, Gaillard J-L, Alouf JE, Berche P. Production of thiol-dependent hemolysins by Listeria monocytogenes and related species. J Gen Microbiol 1989; 135: 481-487.

22. Alouf JE, Viette M, Corvazier R, Raynaud M. Préparation et propriétés de sérums de chevaux antistreptolysine O. Ann Inst Pasteur (Paris) 1965; 108: 476-500.

23. Bradford MM. A rapid and sensitive method for the quantitation of microgram quantities of protein utilizing the principle of protein-dye binding. Anal Biochem 1976; 72 : 248-254.

24. Laemmli UK. Cleavage of structural proteins during the assembly of the head of bacteriophage T4. Nature 1970; 227: $680-685$.

25. Towbin $\mathrm{H}$, Gordon J. Immunoblotting and dot immunobinding - current status and outlook. J Immunol Methods 1984; 72: 313-340.

26. Audurier A, Pardon P, Marly J, Lantier F, Loulergue J. Mesure de la virulence chez la souris de différentes bactéries appartenant au genre Listeria. Ann Inst Pasteur Immunol 1981; 132D: 191-200.

27. McLauchlin J. Listeria monocytogenes, recent advances in the taxonomy and epidemiology of listeriosis in humans. $J$ Appl Bacteriol 1987; 63: 1-11.

28. Espaze EP, Rocourt J, Courtieu AL. La listeriose en France en 1988: étude à partir des souches adressées au centre national de référence. Bull Epidemiol Hebdo 1990; 1: 1-2.

29. Conner DE, Scott VN, Sumner SS, Bernard DT. Pathogenicity of foodborne, environmental and clinical isolates of Listeria monocytogenes in mice. J Food Sci 1989; 54: 1553-1556.

30. Gaillard J-L, Berche P, Mounier J, Richard S, Sansonetti P. In vitro model of penetration and intracellular growth of Listeria monocytogenes in the human enterocyte-like cell line Caco-2. Infect Immun 1987; 55: 2822-2829.

31. Kuhn M, Kathariou S, Goebel W. Hemolysin supports survival but not entry of the intracellular bacterium Listeria monocytogenes. Infect Immun 1988; 56: 79-82.

32. Tilney LG, Portnoy DA. Actin filaments and the growth, movement, and spread of the intracellular bacterial parasite, Listeria monocytogenes. J Cell Biol 1989; 109: 1597-1608. 